\title{
Longevity and Productivity of Three Wolves, Canis lupus, in the Wild
}

\author{
Jim Holyan, ${ }^{1}$ Diane K. Boyd, ${ }^{2}$ Curtis M. Mack, ${ }^{1}$ and Daniel H. Pletscher ${ }^{2}$
}

${ }^{1}$ Nez Perce Tribe Wolf Recovery Program, P.O. Box 1922, McCall, Idaho 83638 USA

${ }^{2}$ Wildlife Biology Program, School of Forestry, University of Montana, Missoula, Montana 59828 USA

Holyan, Jim, Diane K. Boyd, Curtis M. Mack, and Daniel H. Pletscher. 2005. Longevity and productivity of three Wolves, Canis lupus, in the wild. Canadian Field-Naturalist 119(3): 447-448.

We document longevity and productivity of three Wolves (Canis lupus) in the wild in Montana and Idaho, USA. Two male Wolves each attained ages of at least 13 years, while a female was 12.2 years old. All three Wolves in our study were older at the time of their last known reproductive events than others reported in the literature.

Key Words: Wolf, Canis lupus, longevity, reproduction, Montana, Idaho.

Wolves (Canis lupus) are a relatively long-lived species, with individuals in captivity commonly reaching 9+ years, and occasionally living up to 17 years. (Young and Goldman 1944; Goodwin and Ballard 1985; Okarma and Koteja 1987; Mech 1988; Landon et al. 1998; Mech and Boitani 2003). Mech (1988) stated that wild Wolves rarely exceed 13 years of age, and Peterson (1997:13), referring to the protected Wolf population in Isle Royale National Park, stated that maximum lifespan could reach " $10-12$ or even 14 years," though his statement was not supported with documentation. It is reasonable to assume that Wolves 
living in captivity would outlive wild Wolves facing more rigorous environments.

Here, we report on three wild Wolves, 9013, 8756, and B-2, that each attained an estimated minimum age of 12.2 years. These animals were all radio-collared and inhabited Idaho and Montana, USA, from 1987 to 2004. Data for these Wolves were collected using standard radio-telemetry techniques in the Northern Rocky Mountain recovery areas of the USA (U.S. Fish and Wildlife Service et al. 2004).

Ages of Wolves can be accurately determined for individuals $<2.5$ years old based on tooth eruption and wear patterns (Gipson et al. 2000), body size, development and appearance of external reproductive organs, and previous known pack history. Using these criteria, and assuming a mid-April birth date (Boyd et al. 1993; Thurston 2002), we were able to determine the ages for male Wolf 9013 and female Wolf 8756 at the times of their captures. We were only able to estimate male Wolf B-2s age because he was greater than 2.5 years old at the time of his capture.

Male Wolf 9013 was initially captured and radiocollared in September 1990 as a member of the South Camas pack in Glacier National Park, Montana, USA. We determined he was 2.4 years old at the time of his capture. Wolf 9013 dispersed from his natal pack in 1991 to the Kelly Creek drainage of northern Idaho where he remained a lone wolf. In 1995, 15 Wolves were translocated into central Idaho as part of a federal strategy to recover endangered Wolf populations in the Northern Rocky Mountains of the USA (U.S. Fish and Wildlife Service 1994*). By March 1996, Wolf 9013 paired had with female Wolf B-15, one of the Wolves translocated in 1995. They produced a litter of five pups in 1997 and formed the Kelly Creek pack when Wolf 9013 was 8.8 years old. This breeding pair produced subsequent litters in 1998-2000. Wolf 9013 was 11.8 years old when he sired his final litter in 2000.

Wolf 9013 may have been displaced as the alpha male by late 2000 , as he was frequently located apart from other radio-collared members of his pack. The Kelly Creek pack failed to reproduce in 2001. Wolf 9013 was 13.2 years of age when he died from unknown causes in June 2001. An incisor was collected for aging (Goodwin and Ballard 1985). Cementum annuli analysis (Matson's Laboratory, LLC) indicated an age of 8-9 years for Wolf 9013, which underestimated the known age by a minimum of 4.2 years, the error probably caused by extensive cementum resorption (G. Matson, personal communication).

Female Wolf 8756 was captured in Glacier National Park, Montana, USA, as a 5-month-old pup in October 1987. She was monitored weekly with radio-telemetry from 1987-1999. She became the breeding female of the South Camas Pack in Glacier National Park in 1990 at the age of 2.8 years. She apparently produced a litter of pups every year and possibly produced her last litter at 12 years of age. She was 12.2 years of age at the time of her death in June 1999 (Gipson et. al. 2002).

Male Wolf B-2 was estimated to be 4.8 years old when translocated to central Idaho during the federal recovery effort in 1995 . Wolf B-2 paired with a dispersing female Wolf and established the Wildhorse pack, where he fathered litters of pups in 2000 and 2001, at the approximate ages of 9.8 and 10.8 years, respectively. He also sired a litter of four pups in 2003 at approximately 12.8 years of age, after he established the Castle Peak pack. He died at the estimated age of 13.8 years in February 2004. A lower first premolar was collected for aging (Goodwin and Ballard 1985). Cementum annuli analysis (Matson's Laboratory, LLC) indicated an age of 11 years for Wolf B-2.

The two male Wolves reported here lived longer than other longevous wild male Wolves reported in the literature; 9013 was 13.2 years old and B-2 was estimated at 13.8 years old. Mech $(1988,1997)$ reported minimum ages of 11.6 and 11.0 years for the two oldest males he studied. Female Wolf 8756 outlived all but one wild female Wolf reported by Mech (1988).

Both males 9013 and B-2 sired litters at older ages than others reported in the literature. Mech (1988) noted the oldest male Wolf in Minnesota that sired pups was 10.8 years of age; Wolf 9013 was 11.8 years of age in 2000 when he was still believed to be the breeding male of his pack. Wolf B-2 was an estimated 12.8 years old when he was known to be the breeding male of his pack.

Kreeger (2003:193) stated "maximum breeding age for female wolves is not known." Female Wolf 8756 exceeded the maximum breeding age previously reported when she produced pups at 11 years of age, and she may have reproduced at 12 years old.

The value of known-age animals is significant in describing longevity. Estimating age with cementum annuli analysis may not be accurate for Wolves (Goodwin and Ballard 1985; Landon et al. 1998). Gipson et al. (2000) concluded that cementum annuli analysis underestimated actual age by 1-3 years for Wolves $>3$ 14 years of age. Our longevity data for two Wolves of known age and a third with a good age estimation, and their reproductive activity at advanced ages, are noteworthy.

\section{Acknowledgments}

The University of Montana, the U.S. Fish and Wildlife Service, the National Park Service, and the Nez Perce Tribe supported this study. We thank I. Babcock, M. Carter, A. Sondenaa, and two anonymous reviewers for comments that improved this manuscript.

\section{Documents Cited (marked $*$ in text)}

U.S. Fish and Wildlife Service. 1994. The reintroduction of gray wolves to Yellowstone National Park and central Idaho: Final environmental impact statement. U.S. Fish and Wildlife Service, Helena, Montana. 562 pages. 


\section{Literature Cited}

Boyd, D. K., R. R. Ream, D. H. Pletscher, and M. W. Fairchild. 1993. Variation in denning and parturition dates of a wild gray wolf, Canis lupus, in the Rocky Mountains. Canadian Field-Naturalist 107: 359-360.

Gipson, P. S., W. B. Ballard, R. M. Nowak, and L. D. Mech. 2000. Accuracy and precision of estimating age of gray wolves by tooth wear. Journal of Wildlife Management 64: 752-758.

Gipson, P. S., E. E. Bangs, T. N. Bailey, D. K. Boyd, H. D. Cluff, D. W. Smith, and M. D. Jimenez. 2002. Color patterns among wolves in western North America. Wildlife Society Bulletin 30: 821-830.

Goodwin, E. A., and W. B. Ballard. 1985. Use of tooth cementum for age determination of gray wolves. Journal of Wildlife Management 49: 313-316.

Kreeger, T. J. 2003. The internal wolf: physiology, pathology, and pharmacology. Pages 192-217 in Wolves: Behavior, ecology, and conservation. Edited by L. D. Mech and L. Boitani. University of Chicago Press, Chicago, Illinois. 448 pages.

Landon, D. B., C. A. Waite, R. O. Peterson, and L. D. Mech. 1998. Evaluation of age determination techniques for gray wolves. Journal of Wildlife Management 62: 674-682.

Mech, L. D. 1988. Longevity in wild wolves. Journal of Mammalogy 69: 197-198.

Mech, L. D. 1997. An example of endurance in an old wolf, Canis lupus. Canadian Field-Naturalist 111: 654-655.
Mech, L. D., and L. Boitani. Editors. 2003. Wolves: Behavior, ecology, and conservation. University of Chicago Press, Chicago, Illinois. 448 pages.

Okarma, H., and P. Koteja. 1987. Basal metabolic rate in the gray wolf in Poland. Journal of Wildlife Management 51: 800-801.

Peterson, R. O. 1997. The wolves and moose of Isle Royale. Pages 6-14 in World Wide Fund for Nature's Vargsymposium 1997. Edited by L. Nyman and M. Ericson Varldsnaturfonden WWF 3:98.

Thurston, L. M. 2002. Homesite attendance as a measure of alloparental and parental care by gray wolves (Canis lupus) in northern Yellowstone National Park. MA thesis, Texas A \& M University, College Station, Texas. 175 pages.

U.S. Fish and Wildlife Service, Nez Perce Tribe, National Park Service, Montana Fish, Wildlife and Parks, Idaho Fish and Game, and U.S.D.A. Wildlife Services. 2004. Rocky Mountain Wolf Recovery 2003 Annual Report. Edited by D. Boyd. USFWS Ecological Services, Helena, Montana. 72 pages.

Young, S. P., and E. A. Goldman. 1944. The wolves of North America. Dover Publishing, New York, New York. 385 pages.

Received 10 May 2004

Accepted 6 June 2005 